\title{
Kurdish Politics in the Middle East: The Role of the PKK's Changing Policy in Regional Politics
}

BERKAN ÖZGÜR*

\section{The PKK-Kurdistan Workers' Party's Regional Politics During and After the Cold War}

By Ali Balc1

Cham, Switzerland: Palgrave Macmillan, 2018, 212 pages, \$129, ISBN: 9783319422183

\section{Iraqi Kurdistan, the PKK and International Relations, Theory and Ethnic Conflict}

\author{
By Hannes Černy
}

New York: Routledge, 2018, 340 pages, \$64, ISBN: 9781138676176

\section{When Strategy Collapses: The PKK's Urban Terrorist Campaign}

By Murat Yeşiltaş and Necdet Özçelik

İstanbul: SETA Publications, 2018, 200 pages, £17.50, ISBN: 9789752459786

. he transformation of the discourses of the PKK since the 2000 s is placed virtually at the center of Middle East politics as they relate to the Kurdish issue. Particularly, the Syrian civil war and the role of PYD, which is the Syrian branch of the PKK, have made the ideological and discursive evolution of the PKK, and the ways in which this evolving discourse has been implemented, one of the most interesting topics for scholars to elaborate. The evolution of the PKK/PYD affects the decisions of the Turkish government, as well as Iraqi (and other) Kurdish parties in domestic politics, and has directly impacted the course of the Syrian civil war. Therefore, this review article introduces and critically discusses recent contributions to the field of approaching the radical evolution of the PKK.

The books under review approach Kurdish politics from diverse per- 
spectives and contribute to the rapidly increasing literature on Kurdish politics. These books differ considerably in terms of their methodological, theoretical, and empirical approaches toward Kurdish politics and its impact on both the domestic politics of regional states and the relationship between Kurdish parties themselves. The review has two main points. It firstly evaluates the books' theoretical and empirical contribution to the literature of international relations (IR). Secondly, it focuses on the role(s) the authors attribute to the ideological, political and military evolution of the PKK and its impact on regional politics.

\section{Beyond State-Centrism: New Proposals for IR}

Scholars have handled the transformation of Kurdish actors' politics in different ways. However, one perspective, which takes explanatory IR's (International Relations) state-centric approach as fixed, is very prominent in the IR literature. Despite the contribution of IR's state-centric understanding to the field, its assumption of the primacy of the state makes it blind to the practices of non-state armed actors. This reduces the essence of international relations to state-centric interpretations. Moreover, some scholars believe that adherents of this perspective overstate the role of ethnic identity in the politics of Kurdish actors towards other Kurdish groups and toward regional or global actors. Balcı and Černy argue that IR needs a new perspective, a new conceptualization, to complete the explanatory models (Balc1, p. 2; Černy, p. 6).

In this respect, Hannes Černy's Iraqi Kurdistan, the PKKs and International Relations deploys theories of 'ethnic security dilemma' and 'ethnic alliances model' to understand the relationship of the Kurdish parties among each other and with the states of the region, i.e., Turkey, Iraq, and Syria. Černy's book can best be considered a political history account of the Kurdish movement in the Middle East, providing an analysis of the relations of Kurdish parties from the end of the First World War until the Syrian civil war. By reviewing relevant theories, and instead of taking states as the primary actor in world politics, Černy locates Kurdish organizations as "ethno-nationalist parties" (p. 9) at the center of his analyses. In line with this assumption, Černy proposes looking at ethno-nationalist actors such as the PKK, the KDP and the PUK as organizations like states that have security problems, interests, and foreign policies, etc. (p. 9). Černy's account, which looks with suspicion at the capacity of "explanatory IR's state-centric ontology" (p. 6) to understand the nature of ethnic conflict, propounds that "the ethnic alliance model has no explanatory value for understanding actors' behavior" ( $\mathrm{p}$. 185). To support his argument, Černy chronologically analyzes the relationship of Kurdish parties to each other and the regional states, and tries to explain the behaviors of the ethnonationalist parties based on 'group interest' or 'material interest.' Put dif- 
ferently, he interrogates ethnic-based theories which claim that Kurdish organizations have good relationships with other Kurdish parties because of their common ethnicity or common ideology, known as theoretically the "group solidarity" approach (p. 66). Unlike this approach, to explain the relationship between Kurdish groups, Černy takes the notion of "common ethnicity as a strategic essentialism" (p. 163). In other words, considering the ways in which security-dynamics influence the politics of non-state armed groups in addition to the "group solidarity" approach, he recommends a retrospective reading which aims to understand how Kurdish actors react to regional crises and the intervention of Western powers in the region.

Balc1 makes two points that methodologically concur with Černy's argument. First, he interrogates "such traditional schools of IR as Realism and Liberalism" which "accept the state as the only actor in making and practicing foreign policy," and argues that by providing a space for alternative representations, and the ways in which they imagine society/world, "only critical theories such as Feminism, Poststructuralism and Postcolonialism" allow us to study the characteristics of dissident movements (p. 2). Balci's suggestion, in contrast to the state-centric approaches in IR, which mostly focus on the discourse of world politics, intends to understand how dissident ethnic movements "delegitimize the claims of the existing state, [and] contribute in the production of alternative society and its political subjects" (p. 47), and attributes a meaning to the dissident ethnic movements. In this respect, his book is one of the few existing studies that analyze, as a case, the texts about world politics published by the PKK.

Balc1's second methodological novelty lies in its application of ethnic dissident movements to the notion of foreign policy, even if those movements are violent terrorist organizations like the PKK (p. 4). Balc1 regards foreign policy as a form of discursive strategy in the hands of dissident ethnic movements. More specifically, Balc1 explains how the texts published by the PKK regarding world politics contribute to the constitution of Kurdish identity (p. 38). According to Balc1, although most academic research has paid almost no attention to them, the texts published by the PKK reveal so much about the PKK's imagination of world politics, an understanding which changes and evolves along with the contingencies of political conditions. Indeed, when considered from this point of view, Balci's work fills a substantial lacunae in the literature dominated by statecentric approaches.

\section{The PKK: From Kurdish Opening to Urban Conflict}

Turning to When Strategy Collapses, authors Yeşiltaş and Özçelik carefully scrutinize the conflict which occurred between the Turkish state and the PKK in southern Turkey after the failure of the 'solution process' [çözüm süreci] or 'Kurdish opening' 
[Kürt açılımı], which aimed at finding a solution to the Kurdish problem in Turkey. The main aim of the book is to analyze the methods used by the PKK and their changing style, and to politically and technically interrogate why the PKK, which has traditionally fought against the state in rural areas with guerrilla tactics, dissolved the solution process and brought the war into the cities (p. 17).

Yeşiltaş and Özçelik attempt to study the urban conflict initiated by the PKK against the Turkish government in 2013. Unlike studies that seek to understand the political motivation of the Turkish government and the PKK in the solution process and the conflict, the book mostly "focuses on identifying the fundamentals of the PKK's armed strategy during its urban surge, while the analyses of the correlations between the attack type, target selection and attack location contribute to a better understanding of the PKK's armed strategy" (p. 134). In other words, the authors claim that, to explain the political motivation of the PKK, we need to take into consideration the group's increasing armament and military capacity. The book combines approaches from various disciplines like IR theory, sociology, and weaponry. The authors "focus on the details of specific operations carried out through insurgency and define success and failure based on what happens when the tactics used by the organization itself are used against the security forces of any state" (p. 147); in connection with their critical research on urban conflict, this approach provides in- valuable insight into the strategy of terrorist groups.

More interestingly, in addition to technical information on the urban strategy of the PKK, When Strategy Collapses also involves an analysis of the group's political claims, similar to the previous two books under review, focusing on the transformation of the PKK's discourse and its transformative role in the policy of the PKK. In other words, the authors establish a mutual relation between the PKK's armed capacity or tactical elements, and the regional context which includes such events as the Syrian civil war, the rise of ISIS, the July 15 coup deétat attempt in Turkey, and the PKK's increasing role in U.S. policy toward the civil war (p. 25). Yeşiltaş and Özçelik attempt to find a fulfilling answer, both in the political sphere and at the ground level of the armed struggle, for the questions: Why did the PKK initiate a conflict in urban areas and transform its traditional mode of attack? Which political and military conditions facilitated the attacks in urban areas, making it possible/desirable for the PKK to transform its attack types and conflict space?

The current politico-military context makes the questions of the book vitally important: Is there any correlation, beyond political motivation, between the increasing armed capacity of the PKK after enjoying U.S. military support and recognition in the eyes of the Western community, and its intention to use greater military force in more populated areas 
against Turkish government in the solution process? By focusing on the PKK's attacks and its change of tactics after the failure of the solution process, Yeşiltaş and Özçelik's juxtaposition of political explanations and motivations, with the armed strategy used by the PKK, for the first time in its history, locates When Strategy Collapses in a privileged place in the literature.

\section{The Complex Relations of Kurdish Politics}

Many books dealing with Kurdish politics explain the nature of the relations between Kurdish actors in the Middle East based on the ideology of the parties or party identity. According to this assumption, the political identity of the parties brings them closer; therefore, to understand all of their political decisions, many scholars employ explanations based on the ideology of the Kurdish parties. In contrast, in Iraqi Kurdistan, the PKK and International Relations: Theory and Ethnic Conflict, Černy argues that such approaches are right when they claim that sharing a common ethnic identity or common political ideology brings the parties closer at first. However, they are wrong in accepting explanations based on ideological or identical values as the unique model of explanation to understand the political motivation behind their decisions (pp. 27-31). Černy identifies Kurdish parties as ethnic nationalist organizations and their "relations as a complex, shifting and situational matrix of identities" (p. 159). To unravel these complex and shifting relations, he tries to understand the behavior of the Kurdish actors on three levels ( $\mathrm{p}$. 5). First, building on his method, he reads the history of Kurdish movements in the Middle East around a model of explanation featuring the notions of "ethnic alliance," "group interests," "ethnic security dilemma," and "ethnic solidarity." Thus, he tries to understand the main motivation behind the decisions of the Kurdish parties in both a regional and international context. Secondly, he conducts interviews with academics, journalists and active Kurdish politicians in Iraqi Kurdish parties, which make his explanations more clear at an individual level as he seeks to deconstruct the discourse of the actors (p. 15).

According to Černy, complex developments in Kurdish politics occurred in the 1990s. During that decade, the political positions not only of nonstate groups (the $\mathrm{PKK}$, the KDP, the PUK), but also of the regional actors (Iraq and Syria), changed many times. The political atmosphere of that decade created difficulties for understanding the motivations and decision-making mechanism of Kurdish actors. To explain these "complex relations" Černy arguably takes identity and ideology as effective factors at the individual level, while claiming that the material interests of the parties gain an explanatory value at the regional and international level (p. 158).

Although the author takes explanations based on ethnic identity into 
consideration, he argues that group interests or material interests of the ethno-nationalist parties are also a vital factor shaping the political decisions of the groups. Eventually, Černy "find[s] it very difficult if not impossible to draw a clear line between political ideology and ethnicity determining these groups' [the PKK, the KDP, and the PUK] behaviours" (p. 159). To put it differently and more clearly, he uses his approach for providing a better explanation. For example, while the author explains the PUK's support of the PKK in 1979-1980 with reference to the "ethnic alliance model," he argues that the ethnic alliance model does not work to explain the actors' behavior when their relations become more international. Despite the common ideological leftist character and common ethnicity it shares with the PKK, the PUK collaborated with the KDP against the PKK in the same years of the 1990s, according to the author, mostly because, "dependent on Turkey and the international community for their survival, the KDP/PUK had to confront the factor that could jeopardize their newly gained political relevance; that is, they fought the PKK because it posed a vital threat to their political relevance" (p. 186). Additionally, Černy assesses that the relations of the KRG with the PKK gradually worsened as the KRG's relations with regional and international actors increased. In other words, as the KRG become more dependent on Ankara and the international community, its group interest become more important than its ethnic identity. Briefly, Černy thinks that sharing common ethnicity or common ideology does not suffice to explain groups' relations or cooperation at the international level, where they would need to have the same strategic purposes to cooperate (pp. 232-233).

As mentioned above, the author considers non-state actors as sovereign 'states' in their own right, with their own concerns regarding sovereignty, border security, foreign policy, territorial control, etc. In other words, Černy pays attention to ethnic-nationalist movements because of the fact that their material interests influence their decision making process as well as their group identity or ideology. Although Černy's assumption, i.e., considering non-state ethnic movements as states, has to date drawn little attention in academic writing, it has increased steadily as an interest in the emergent literature in tandem with the increase in the importance of the role of non-state ethnic movements in regional politics. Balci's study is one of the prominent, welcome contributions to this understudied research area which provides an alternative lens to more standard IR approaches. Similar to Černy, Balc1 also equates ethnic movements with states and, mostly focusing on discourse, argues that ethnic movements, by producing alternative representations of identity, use "external references to normalize, consolidate, and reconsolidate their positions against each other" (pp. 5-6). As such, Balci's main motivation in The PKK-Kurdistan Workers' Party's Regional Politics During and After the Cold War is that much of the extant 
scholarship "overstate[s] the role of the Kurdish elite and exclusionary practices of the Turkish state as the only condition of Kurdish nationalism” (p. 59). More importantly, Balc1 argues that these studies draw insufficient attention to "the emergence and constitution of the post-1980 Kurdish political identity" (p. 9).

In this sense, Balcr discusses the importance of the political imagination of ethnic dissident movements with a special focus on the texts produced by the PKK as a case study. Balc1 asks, is it "possible to speak about the 'foreign policies' of ethnic dissident movements, especially when considering that they have no characteristics of modern sovereign states such as territory, border, and recognition?" (pp. 1-2). If so, as David Campbell famously notes, for states' foreign policy discourses and practices, it can be argued that ethnic (dissident) movements' foreign affairs and discourses of world politics aimed at de-legitimating the targeted nation-state, "play an important role in the construction of identity and exercise of power relations" (p. 17). In line with this argument, Balci's main focus is on the PKK's writing of world politics, which, the author acknowledges, plays a vital role in the construction of a counter-narrative against the state's hegemonic imagination of world politics.

In this context, the author attempts to pin down the role of the counternarrative produced by the PKK as an authoritative actor in the emergence of Kurdish political subjectivity. Ac- cording to Balc1, the texts on world politics published by the PKK serve two main aims. Firstly, and before everything else, the PKK not only speaks about world politics but also, by excluding existing traditional and alternative Kurdish narratives, re-constructs Kurdish political subjectivity. To say it more clearly, the PKK transforms Kurdish identity and reshapes it in a context of resistance against the Turkish state' hegemonic narrative (p. 11). Further, Balc1 stresses the transformative effects of world politics discourse in re-constructing Kurdish identity. Put differently, the author claims that Kurdish identity, as it is reshaped in the hands of the PKK is not fixed; it has changed dramatically depending on political conditions. More specifically, Balc1 focuses on the representations of the USSR and the U.S. during the Cold War and their radically changing positions after the end of the Cold War. In contrast, the representations of the U.S. and Turkey take the form of a fixed 'external other' during and after the Cold War (pp. 75-76). According to Balc1, representations of the regional and global actors such as the U.S., the USSR, the KDP, and the PUK, which are identified in the PKK's texts as the Kurds' 'other,' 'enemy', and 'threat,' and are theoretically labelled by Balc1 as the 'external other' and 'internal other', tell us much about the discourse's transformative effects in reshaping Kurdish identity (p. 140).

As for the second task of the texts, according to Balc1, "the PKK not only re/constructed the ground for 
the new Kurdish identity but it also emerged as a disciplinary power over the new and distinct Kurdish subjectivities" (p. 74). Theoretically speaking, the discourses of the dissident movements' world politics, which delegitimize the hegemonic narrative of the targeted nation state, dissolve the tie between the state and its citizens and open a space for new and alternative power. Similarly, by undermining the discourse of states' power (as 'external other') and other Kurdish actors' (as 'internal other'), the PKK creates for itself a privileged position among the Kurdish population not only in Turkey but also in the Middle East, and legitimizes both its privileged, hegemonic position and its use of violence. From a similar angle, by re-writing Kurdish history in its own words, the PKK builds Kurdish identity through insurgent, emancipatory discourses, and creates a role for itself in the so-called emancipation of the Kurds from both occupying states and imperialist power, thereby construing the PKK as a new center of power, specifically locating itself as "a true representative of the Kurds" ( $p$. 11). For instance, according to Balc1, the ideology of socialism becomes as a useful instrument in the hands of the PKK, as evidenced in its claims that Marxist-Leninist ideology could put an end to the occupation of Kurdistan. Thus, the PKK legitimizes the necessity of a leftist Kurdish movement, which carries out attacks of violence against the Turkish state, which is a member of the imperialist bloc led by the U.S. (p. 113). In all, the author persistently underscores that his "book primarily aims to tackle the regulatory and productive power of dissident ethnic movements that constructs different kinds of knowledge and subjectivities" (p. 48).

\section{The Syrian Civil War: Catalyst for the PKK's Shifting Relations}

As Balc1 mentions, the representations of the U.S. in the discourse of the PKK has always been at the center of the texts, and has typically carried negative connotations for the Kurds (p. 2). However, the Syrian civil war led to a number of consequences for regional actors; the conflict marks a turning point for the PKK and its relations with external actors, especially the U.S. As is well-known, the PYD, a leftist organization and the Syrian branch of the PKK, has surprisingly enjoyed U.S. military support and increasing relations with Western powers, thanks mostly to its fight against ISIS. As Černy stresses, the most fundamental material interests of ethnicnationalist movements reframe their politics towards non-state groups and the states (p. 71). Yeşiltaş and Özçelik argue that the changing political and military atmosphere epitomized by the U.S.'s support for the PYD in Syria affects domestic politics in Turkey. Yeşiltaş and Özçelik claim that the increasing military capacity of the PKK in the Syrian civil war has transformed its politics toward the Turkish government. One of the most prominent flashpoints, the 'Kobani Protest' on October, 6-8, 2014, and its aftermath, show that the U.S. military support, and the PYD's recognition in the Western gaze after Kobani's 
siege by ISIS provides a fertile ground to further engage the Kurdish public and to perpetuate armed conflict in Turkey (Yeşiltaş and Özçelik, pp. 25-26).

As Yeşiltaş and Özçelik argue, the PKK's reinstigation of armed conflict, which put an end to the solution process, differentiated from its traditional armed strategy, which had been confined to rural areas since the first attack of the PKK in 1983. The authors believe that the PKK's main motivation was its increasing military capacity and the increasing experiences of its militants in street fighting in the Syrian civil war. This changing military strategy, called by Öcalan a 'new defensive war' or 'revolutionary people's war,' which intends to create isolated areas in southern Turkey aims to "force an ethnic-based homogenous geopolitical corridor, contributing to the emergence of a significant autonomy by seizing territorial control over time" (p. 25). To do this, instead of using guerrilla tactics to target the state's security forces and village guards (köy korucuları), the PKK has diversified its kinds of attacks, the main characteristics of which are now to gain the support of the people living in conflict zones, through what is termed "irregular warfare," "in order to influence the people or with the aim of legitimation" (pp. 33-36).

As the Kobani Protests show, the young people who act as an organic part of the PKK are a fundamental part of the PKK's urban strategy. Those young people, aged between
15 and 25 and unified under the Revolutionary Patriotic Youth Movement (YDG-H), trained and gained experience in Iraq and Syria before and during the battles which are represented by the PKK as the "ISISKurdish War." Such a representation facilitates the rapid radicalization of the young people (pp. 41-49). The same line of propaganda not only radicalizes young people but also becomes a political tool in the hands of the PKK to legitimize its violent actions in the eyes of the Western/ international community and the local populous (p. 78). According to Yeşiltaş and Özçelik, the final stage of the legitimation process, by justifying its armed struggle, "aimed at pushing the government forces out of the claimed territory" (p. 82).

Finally, however, the strategies that the PKK used in its urban conflict against state's security guards turned into the cause of its defeating (p. 107). Sifting through the many reasons behind the failure of the PKK, Yeşiltaş and Özçelik mention five strategic mistakes: lack of experience among the young militants and lack of military capacity, lack of public support, the PKK's strategic priority of its survival within the Syrian war, Turkish security forces' military reaction, and the lack of outside support (p. 149).

\section{Non-State Armed Groups: Grounds for Further Study}

Focusing on the discursive, political and military evolution of the PKK, the above studies answer three main 
questions: (i) How historical conditions and recent regional developments have forced the PKK to transform ideologically and military, (ii) How the PKK uses ideology as a discursive strategy to evaluate its policy dependent on regional crises, and (iii) How the transformation of the PKK affects its relations with other Kurdish parties and Western powers. Moreover, the authors underscore the importance of expanding research into the policies of non-state armed actors, forming a counter-narrative and addressing the policy of violence. Indeed, as scholarship addressing non-state armed actors proliferates in the wake of the Syrian civil war, so does the need to continuously expand and understand the changes to the geo-political landscape effected by non-state armed groups. 